\title{
Hidden Children: Using Children's Literature to Develop Understanding and Empathy Toward Children of Incarcerated Parents
}

\author{
VAL PLETT REIMER \\ University of Manitoba
}

\begin{abstract}
Research indicates that children whose parents are incarcerated are a vulnerable group of people with poor life outcomes. Yet these children are not tracked in the Canadian system, making it difficult for schools to respond with appropriate supports. How can schools be inclusive to this hidden demographic of children? Framed in theories of Ethic of Care, Reader Response, and Critical Literacy, the author proposes the use of story to develop understanding and empathy. Research shows that acknowledging these children's experiences through story helps them to feel validated while broadening capacity for empathy among other children. Can a story develop empathy toward children of incarcerated parents? To answer this question, the author wrote a picture book about a child who visits her mother in jail, and read the story to three groups of children, interspersed and followed by rich discussions. The story elicited empathetic responses from all students, suggesting the benefits of this approach.
\end{abstract}

\section{Introduction}

There are many children in Canadian schools who have a parent(s) serving time in correctional facilities. These children face a range of obstacles, such as poverty, academic difficulties, and social and emotional stresses (Bayes, 2007; Dallaire, Ciccone \& Wilson, 2010). Although there is a growing recognition that teachers can provide valuable support to children of incarceration, the authors of a study focusing particularly on teachers' experiences with children of incarcerated parents, say they "could not locate a single study that has investigated teachers' experiences with children with incarcerated parents" (Dallaire et al., 2010, p. 282). There is a great need for research that looks at the needs of these children, so that teachers have a better understanding of how to best support them. Without support, the challenges that children of incarcerated parents face can be overwhelming and even insurmountable. Yet, these children remain part of an unidentified demographic across Canada. As McCormick Millar, Paddock, \& Cohen point out, "there is no systematic process in place to identify school children affected by parental incarceration" (2014, p. iv). How can children be supported if we don't know who they are? And how can schools help to meet their needs?

A healthy classroom culture is one that encourages children to think critically while nurturing warmth and compassion. For this reason, I have framed my study in theories: Ethic of Care, Reader Response, and Critical Literacy, and I will offer a brief explanation and rationale of these theories. Following that, I want to discuss the function of inclusive literature in today's classroom and the role it might play to help students develop in their awareness and empathy toward children of incarcerated parents, so that they will feel less isolated and more understood and included. Finally, I want to share a summary of the responses that children in three focus groups from two different schools and communities 
had to the story, Sammy's Visit. In order to offer support, it is important to understand some of the realities and daily challenges that children of incarcerated parents face. To that end, I want to begin by offering some perspectives on who these children are and some of the issues they deal with.

\section{Children of Incarcerated Parents: An Unidentified Demographic}

To help situate children of incarcerated parents, we need some familiarity with Canada's correctional demographic. It is helpful to know for example, that according to Statistics Canada:

- Correctional facilities across the country are overcrowded.

- Indigenous peoples are disproportionately represented in correctional centres in Canada's provincial and territorial correctional centres.

- Mental illness, addiction, poverty, histories of abuse, and memories of childhood trauma are among the realities that many in our correctional centres live with.

- Incarcerated women have, on average, more children than other women, and Indigenous women (both incarcerated and non-incarcerated) have, on average, more children than non-Indigenous mothers.

- The majority of incarcerated men and women do not have high school diplomas.

- A large percentage of currently incarcerated inmates have grown up in settings of familial incarceration. Children of incarcerated parents appear to have a higher probability of being incarcerated in adulthood than those of nonincarcerated parents.

These realities have significant implications for our schools as they directly affect children of the incarcerated. Though numbers of children impacted are not officially tracked, Canada's high incarceration rates (106 per 100,000 adults, according to Statistics Canada, 2015) would indicate that many thousands of students in Canadian schools live with the reality of having a parent who is incarcerated. Such correctional statistics tell a dismal tale in a country that claims to honour the rights of children. All too often, these children's lives become a sad sequel to the current narrative being played out in their parents' lives.

Children of incarcerated parents are an unidentified demographic in Canada's provinces and territories as this information is neither tracked nor passed on to the schools by the Department of Justice, making it very difficult for schools to help these children deal with the issues they will face-issues that are unique to parental incarceration (McCormick et al., 2014). A 2007 research report by Correctional Service Canada recognizes "there is limited data about parents who are incarcerated. Further information on the parental status of Canadian offenders is required in order to address this issue through policy and program development" (Correctional Service Canada, 2007). Unless the children, their families or their caregivers choose to disclose such information, the schools have no way of knowing that parental incarceration could be impacting their students. This presents a major obstacle for educators who may want to offer targeted support to these children. Quoted in a blog post, McCormick, a criminology professor, stresses the importance of considering the well-being of children when sentencing their parents: 
When people are sentenced to custody, there is no protocol for considering whether they have dependent children and what effect the parent's sentence will have on the child. Yet, it is important to consider the best interests of a child because maintaining family relationships can be an extremely important factor in reducing parents' chances of reoffending, as well as preventing a child's future anti-social behaviour. (Russell, 2014)

This is not to say that needs exhibited by children of incarcerated parents are never met by educators. For example, if a child suffers academically, socially or in other noticeable or measurable ways, supports can and should be put in place to help children of incarcerated parents as they would for anyone else. However, if parental incarceration is the underlying cause of an exhibited need, and teachers and support workers were to be aware of this, such knowledge could impact and change an intervention plan. For example, a child struggling to write may be more motivated if an understanding teacher suggested she write a letter to her mom or dad in jail, or arranges for projects to be taken home so they can be shared during correctional visits. If correctional visits are only allowed on weekdays, a teacher should make allowances for necessary absenteeism and encourage such visits. It would be forward thinking indeed if correctional centres were to offer incarcerated parents of school children video conference time to facilitate parent-teacher meetings. All parties could potentially benefit by such dialogues that attempt to break down barriers. The teacher would have a better understanding of where the child is coming from, the parent would have the opportunity to enter into their child's school life, and the child would have the opportunity to be better understood. By recognizing and working within their realities, children's experiences are normalized and they will feel less isolated (Morgan, Leeson, Dillon, Wirgman, \& Needham, 2014). The pain that children feel when a loved one is absent, the shame and guilt that is often associated with the separation, and the "family secret" they are sometimes expected to keep all have the potential to further stigmatize and isolate these children. It is not the child's fault when a parent is incarcerated, and yet isolation and stigmatization often adds to the suffering that such a child is already made to endure (Bayes, 2007).

There are a number of examples around the world (such as the UK, Australia, USA) that politically recognize this vulnerable group of children with the purpose of offering more supports within the school community. Although such policy changes could go a long way to benefit children of incarcerated parents in Canada, the current reality in all Canadian provinces and territories is that the decision to disclose parental incarceration rests with the child, parent and/or caregiver (McCormick et al., 2014). So, how can teachers meet the unique needs of children of parental incarceration when these children are not identified as such?

Theoretical Underpinnings: Ethic of Care, Reader Response \& Critical Literacy

Children bring their backgrounds with them when they come to school. The families they come from, and the social and emotional burdens they carry, will affect their interactions and performance at school. Teachers need to respond to students with compassion by showing interest in and caring for them as individuals. This includes flexibility with and broadening subject areas so as to meet the needs and interests of the child (Noddings, 2005). To do so is not to ignore the educational mandate that teachers are 
entrusted with. On the contrary: "To have as our educational goal the production of caring, competent, loving, and loveable people is not anti-intellectual. Rather, it demonstrates respect for the full range of human talents" (Noddings, 1995, p. 2). Caring for our students includes creating opportunities that help to give voice to difficult experiences, in order to limit feelings of isolation they may face.

I draw on The Ethic of Care theory developed in the 1980's by feminist Nell Noddings. What Noddings promotes is a highly relational ethic, as it takes the responses and feelings of others into account. An ethic of caring returns us to...the relations in which we all must live. A relational ethic is rooted in...natural caring" (Noddings, 1988, p. 219).

Part of developing and cultivating environments of care involves teaching students to care for one another. Teachers do this by role modeling attitudes and behaviors of care, but we must also actively teach children to care for each other. Noddings addresses the importance of this: "In a classroom dedicated to caring, students are encouraged to support each other; opportunities for peer interaction are provided, and the quality of that interaction is as important (to both teacher and students) as the academic outcomes" (Noddings, 1988, p. 223).

Louise Rosenblatt also stresses the importance of recognizing children's backgrounds and interests, particularly as they pertain to meaning children ascribe to their reading. The background experience, knowledge, and interests of children play a profound role in how text is interpreted, understood, and enjoyed. Her work focuses on what children bring with them to the literary text. Also known as Transactional Theory of the Literary Work, Rosenblatt developed the Reader Response theory in the 1960's in response to textbased theories that dominated the landscape up to that point. Greatly influenced by Dewey and James, she "advanced a transactional theory of the literary work, which highlights the dynamic, generative relationship between the reader and the text in the formation of meaning" (Connell, 2005, p. 69). The reader's involvement and personal response is integral to literary theory. Says Rosenblatt, "The words of a poet remain merely black marks on the page until they are brought to life anew by his readers in the context of their own worlds" (1960, p. 304).

This research is also built on a Critical Literacy framework. Critical Literacy has grown out of Paulo Friere's philosophy of social justice and his active work among oppressed communities in Brazil, which he wrote about extensively in Pedagogy of the Oppressed. Like Noddings, Freire speaks to the importance of dialogue. He wants to ensure that those who are marginalized are part of dialogues that will impact them. To dialogue with others, one needs to be caring and loving. "Love," says Freire (1970) "is at the same time the foundation of dialogue and dialogue itself... if I do not love life-if I do not love people-I cannot enter into dialogue" (pp. 70-71). He goes on to say that "true dialogue cannot exist unless the dialoguers engage in critical thinking" (Freire, p. 73). Freire compares the education system to a banking model, void of human emotion, and he suggests that critical thinking is neither evident nor valued in our schools. Luke (2012) summarizes Freire's ideas and concerns well:

He argued that schooling was based on a 'banking model' of education where learners' lives and cultures were taken as irrelevant. He advocated a dialogical approach to literacy based on principles of reciprocal exchange. These would 
critique and transform binary relationships of oppressed and oppressor, teacher and learner. (p. 5)

Friere's life work was devoted to empowering those who were disempowered, oppressed, and marginalized. Today, Friere's vision continues to guide critical literacy theory as it focuses "on the uses of literacy for social justice in marginalized and disenfranchised communities" (Luke, 2012, p. 5).

Critical literacy has been defined in many ways. Lewison, Flint, and Van Sluys (2002) have reviewed and synthesized these definitions grouping them into the following four dimensions: "(1) disrupting the commonplace, (2) interrogating multiple viewpoints, (3) focusing on sociopolitical issues, and (4) taking action and promoting social justice" (p. 382). They point out that these dimensions are interrelated and none of them standalone. The goal of the first dimension: 'disrupting the commonplace' is to explore a text with a new perspective, or "seeing the 'everyday' through new lenses" (Lewison et al., 2002, p. 383). The second dimension: 'interrogating multiple viewpoints' asks us "to imagine standing in the shoes of others - to understand experience and texts from our own perspectives and the viewpoints of others and to consider these various perspectives concurrently" (Lewison et al., 2002, p. 383). The third dimension of critical literacy: 'focusing on sociopolitical issues' considers power relationships and explores how "sociopolitical systems and power relationships shape perceptions, responses, and actions" (Lewison et al., 2002, p. 383). Finally, the fourth dimension of critical literacy: 'taking action and promoting social justice' focuses not merely on action, but on reflective action. Students are encouraged to think critically about inequity and to find concrete ways to bring about change toward greater social justice. Dresang \& McClelland speak about a fundamental shift that is happening in the way children read and think in this digital age. They have broken this down to "three major types of changes occurring: changing forms and formats, changing perspectives, and changing boundaries (in subject, character, and theme)" (1999, p. 161). Such shifts in children's thinking align well to Lewison et al's four dimensions of critical literacy.

Caring for others involves knowing and understanding others. Taking the time to know our students helps to build trust with them. In fact, it is easier to care for others when we understand them and are able to see things from their perspectives. Friere, Rosenblatt, and Noddings all speak about the importance of caring for and knowing our students. Freire speaks to the importance of "...understanding learners' life worlds, with the aim of framing and solving real problems" (Luke, 2012, p. 5). It is significant that Freire's book is entitled, "Pedagogy of the Oppressed" and not, "Pedagogy for the Oppressed" because it indicates that he actively involved learners in the process of learning. Rosenblatt speaks to the importance of knowing our students, and supporting them in the process of self-reflection, so that students can grow as they learn to understand their own responses to what they read. Says Noddings, "Teacher and student must know each other well enough for trust to develop" (1988, p. 223).

To help children of incarcerated parents, teachers must understand who they are and where they come from. "To shape such persons, teachers need not only intellectual capabilities but also a fund of knowledge about the particular persons with whom they are working" (Noddings, 1988, p. 221). Collecting this "fund of knowledge" about our students involves knowing and understanding our students and the realities that children of 
incarceration typically live with, and this involves having at least a rudimentary understanding of who their parents are and the circumstances surrounding their parents while incarcerated.

\section{The Power of Story}

Bringing greater awareness, at the school and classroom level, of the lived experiences of children of parental incarceration is a first step toward recognizing the realities that these children live with. According to Maich and Belcher (2012), "Peer awareness can be thought of as the foundation to inclusion in the classroom, paving the way for further direct interventions and opportunities" (p. 207). Such recognition has the potential, says Lea (2015) to help children in the margins feel less isolated. Picture books have the ability to deliver on that front as they can be used to support and nurture peer awareness (Maich \& Belcher, 2012). Even in addressing sensitive topics such as stress and child abuse, Smith-D'Arezzo and Thompson (2006) speak to the importance of children's literature. They write, "Children benefit greatly from reading literature that reflects authentic situations in life, situations they can relate to" (p. 335). They go on to add, "We want the messages to be healthy and authentic; to give abused children hope; and to help other children understand people and their situations; and as children get older to encourage them to be advocates for others" (p. 336). The weaving of a narrative has the potential to bring awareness to a concept in a way that a mere delivery of facts fails to do. By endowing an idea with a human face, feelings and human interactions - as is often the case with picture books - potential is created to help children grow not only in knowledge, but also in empathy and in social imagination, touching not only the mind, but also the heart. Say Lysaker and Sedberry (2015), “...it is the deep empathetic response and engagement in social imagination that creates a new relational context within a reading event that can promote learning and personal transformation" (p. 106). This underscores Rosenblatt's theory that individual response to text is as important as the text itself. "Literature equals book plus reader" (Rosenblatt, 1960, p. 306).

It is important not to lose sight of the children and their needs in the choosing and delivery of reading materials that support the growth of emotional intelligence and the development of empathy. Reading stories to children is an effective way to broaden their experiences, while helping them to change perspectives and grow in empathy. "Extensive and intensive engagement with good literary texts through adult-mediated reading can encourage children's empathy development, which is healthy for individuals" (Riquelme \& Montero, 2013, p. 236).

For children of incarcerated parents to feel less isolated, their experiences need to be understood more widely by others. Well-told stories have the potential to cultivate understanding and empathy in other children, who may never have thought about the impact that incarceration could be having on their peers. Stories can powerfully shape the way we think, and picture books have the additional visual component that can aid children in developing greater understanding. Picture books are accesible and effective tools that teachers have at their disposal to shape young minds.

\section{Stories Provide Safety}

Stories also provide a safe environment for children to learn and to enjoy vicarious experiences while exploring the world of feelings and allowing empathy a chance to take root and develop. Safety is an essential component in a healthy classroom community, and 
as Sapon-Shevin (1999) reminds us, such "safety cannot be mandated; it must be created" (p. 37). Reading stories to children is an excellent way to create a safe space for children. Stories that focus on another have the potential to help children of incarceration to feel safe and less vulnerable. While it is important that the story character parallels some of the difficulties experienced by children of the incarcerated, the use of story also deflects attention off of the self and helps to create a comfortable distance for these children. SmithD'Arezzo and Thompson (2006) speak to the importance of such separation. Though they speak specifically about stress and child abuse, this principle might be generalized to other difficult situations such as learning to cope with challenges associated with parental incarceration. Smith-D'Arezzo and Thompson argue:

Sometimes, when the abuse is separated from the child's life and is happening to someone else, for example the characters in a children's book, the topic may be discussed more easily between adults and children, and children may be more apt to talk about what is happening in their lives. (p. 337)

Stories can be an effective instructional strategy to promote peer awareness, as they have the ability to provide not only a creative outlet, but also a sensitive avenue in that picture books telling the story of another might prevent a teacher from inadvertently inflicting more shame and unwanted attention than children of the incarcerated may already suffer.

\section{Stories Develop Understanding \& Empathy}

Stories have been used effectively to help children learn about a whole array of human conditions, such as: autism, race, sexual orientation, and poverty. Such stories help children learn about people both like and unlike themselves, and can help to develop greater understanding and empathy. For example, in a research project involving three groups of grade two children (70 in total), Dever, Sorenson, and Brodrick (2005) used pictures books "as a vehicle to teach young children about social justice" (p. 18). Fly Away Home by Eve Bunting is a story about a homeless father who lives at an airport with his young son because he cannot afford to pay rent. This story evoked empathetic responses when it was read to the groups of children; many "were saddened and decried that it is not fair that some people are homeless" (Dever, et al, 2005, p. 20). Amazing Grace, by Mary Hoffman and Caroline Binch is a story of a young girl who loved to act and hoped for the role of Peter Pan in their class production. "Grace's classmates tell her that she can not play Peter Pan in the play because she is a girl and she is black" (Dever, et al, 2005, p. 19). Saddened but not dissuaded, her practice paid off and she was finally rewarded with the role she had hoped for. Children in the research project "were not only empathetic, but were moved by this story to take action and advocate on Grace's behalf" (Dever, et al, 2005, p. 21).

When children read stories about children like themselves (Miller, D., 2012)characters that they can relate to-it helps them to connect with literature, and it normalizes experiences that can otherwise be very isolating (Lea, 2015). Acknowledging children's experiences with creativity, integrity, and sensitivity has the potential to help children of incarceration feel less alone and more understood, essential components for healthy child development (Lowe, 2009).

It is equally important for children whose experiences are quite different from those of the fictional character to read such stories so that their perspectives are given a chance 
to change and grow. Stories about troubled lives or about children with disabilities have been used to broaden the worldview of those who may have no understanding of, or given little thought to an issue. Also known as inclusive literature, such stories have been used effectively to help others develop understanding and empathy toward children who may be misunderstood. Picture books are a wonderful way to enlarge a child's experience, and in so doing, develop empathy. In bringing a human face to the difficult topic of incarceration, and in telling a story in an age appropriate way, we as educators have a wonderful opportunity to help children enter into the experience of others. For empathy to have a chance to take root and develop, children's perspectives need to be challenged. For example, viewpoints may unknowingly be based on fear and misinformation; a child's perspective about prison could well be shaped by images and messages seen in the mass media. Images of dangerous offenders may come to mind, even though in reality, this particular demographic is relatively small. (According to Statistics Canada, 2010/2011, $76 \%$ of provincial and territorial sentenced offenses are of non-violent nature). If this same child reads a story about a little girl who misses her mother, a mother who regularly reads stories to her, the fact that she is serving a prison sentence may be seen in another light, because now the reader has a better chance of relating to this domestic and comfortable scene. There is still tension in this story to be sure, but there is enough familiarity in place for the reader to begin to form new perspectives. With new perspectives, hopefully students will "begin challenging stereotypes and misconceptions" (Labadie, Pole, \& Rogers, 2013, p. 313).

When new perspectives give readers greater understanding and empathy, then children of incarcerated parents may open up, and trusting, caring relationships between themselves and other children may start to form. If stories have the potential to help children become more empathetic, as Lysaker and Sedberry (2015), Nikolajeva (2013), Maich and Belcher (2012) claim, then sensitively told stories about incarceration have the potential to help children become more empathetic toward those who are impacted by parental incarceration. The hope of course would be that such understanding would lead to greater social inclusion, so that children of incarcerated parents might feel less isolated. To feel understood and socially included could be an important first step toward helping children of incarcerated parents to be successful in school. Inclusionary practice is important for these children. Healthy beginnings and success in school will reduce chances of their future incarceration and increase the possibilities of living productive and meaningful lives.

Table 1

Picture Books on Incarceration Theme

\begin{tabular}{|l|l|l|l|}
\hline Title & Author & ISBN-13: & Date \\
\hline Amber Was Brave, Essie Was Smart & Vera Williams & $\begin{array}{l}978- \\
0060571825\end{array}$ & 2001 \\
\hline $\begin{array}{l}\text { Far Apart, Close in Heart: Being a } \\
\text { Family when a Loved One is Incarcerated }\end{array}$ & Becky Birtha & $\begin{array}{l}978- \\
0807512753\end{array}$ & 2017 \\
\hline Hazelnut Days & $\begin{array}{l}\text { Emmanuel } \\
\text { Bourdier }\end{array}$ & $\begin{array}{l}978- \\
9888341542\end{array}$ & 2018 \\
\hline
\end{tabular}




\begin{tabular}{|l|l|l|l|}
\hline Letters to a Prisoner & $\begin{array}{l}\text { Jacques } \\
\text { Goldstyn }\end{array}$ & $\begin{array}{l}978- \\
1771472517\end{array}$ & 2017 \\
\hline My Daddy's In Jail & Anthony Curcio & $\begin{array}{l}978- \\
0692470435\end{array}$ & 2015 \\
\hline My Daddy's In Jail & Janet M. Bender & $\begin{array}{l}978- \\
1889636481\end{array}$ & 2003 \\
\hline $\begin{array}{l}\text { The Prison Alphabet: An Educational } \\
\text { Coloring Book for Children of } \\
\text { Incarcerated Parents }\end{array}$ & $\begin{array}{l}\text { Dr. B. } \\
\text { Muhammed \& } \\
\text { M. Muhammed }\end{array}$ & $\begin{array}{l}978- \\
1939509093\end{array}$ & 2014 \\
\hline The Night Dad Went to Jail & Melissa Higgins & $\begin{array}{l}978- \\
1479521425\end{array}$ & 2013 \\
\hline Visiting Day & $\begin{array}{l}\text { Jacqueline } \\
\text { Woodson }\end{array}$ & $\begin{array}{l}978- \\
0147516084\end{array}$ & 2002 \\
\hline When Dad was Away & Liz Weir & $\begin{array}{l}978- \\
1845079130\end{array}$ & 2013 \\
\hline
\end{tabular}

Novels:

\begin{tabular}{|l|l|l|l|}
\hline \hline I am a Taxi & Deborah Ellis & $\begin{array}{l}\text { 978- } \\
0888997364\end{array}$ & 2006 \\
\hline Jakeman & Deborah Ellis & $\begin{array}{l}978- \\
1550415759\end{array}$ & 2007 \\
\hline The Same Stuff as Stars & $\begin{array}{l}\text { Katherine } \\
\text { Paterson }\end{array}$ & $\begin{array}{l}978- \\
0618247448\end{array}$ & 2002 \\
\hline
\end{tabular}

Sammy's Visit: A Read-Aloud

Research shows that acknowledging children's experiences through story helps them to feel validated while broadening capacity for empathy among other children. Can a story develop empathy toward children of incarcerated parents? I set out to look for some answers, but as there are a limited number of picture books for young children on the topic of parental incarceration, and as there are even fewer picture books written by Canadian authors or written from the perspective of maternal incarceration, I decided to write the story, Sammy's Visit. 


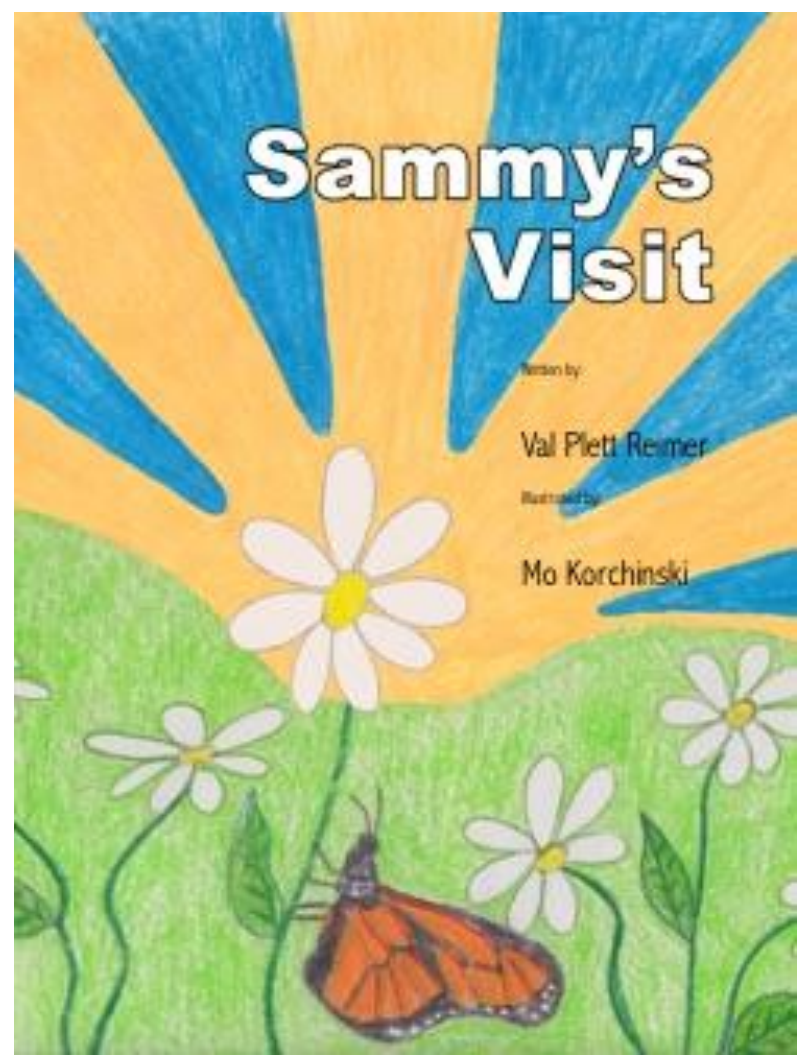

Figure 1. Cover Image

The writing of Sammy's Visit was inspired by an interaction I observed early on in the six years that I spent teaching in a women's correctional centre. As I was leaving work one day, I walked through a room where a guard was supervising an inmate having a visit with her two children. The mother - a woman about my own age- held a baby on her lap. While rocking her baby gently, she stared into the room. A young girl, who looked to be about 9 years of age stood awkwardly at her side. The mother was a student of mine for a short while before she was released, and though I hadn't had the opportunity to know her well, I witnessed, ever so briefly, a side of her that I'd never seen in the classroom. I knew her to be a hard working, quiet and friendly woman. What is etched in my memory is the look of deep sadness I observed in that moment. "And the child? What of the child?" This was the disquieting question that would not go away. As I was to learn later, this mother was one of the 'lucky ones'. While many incarcerated parents are denied physical contact with their children, she was able to hold her child. She also had a loved one in her life who brought her children to the facility for visits. These are the hopeful images I held on to and wanted to portray in Sammy's Visit in hopes that the story would not only compel, but would also resonate with young readers. 


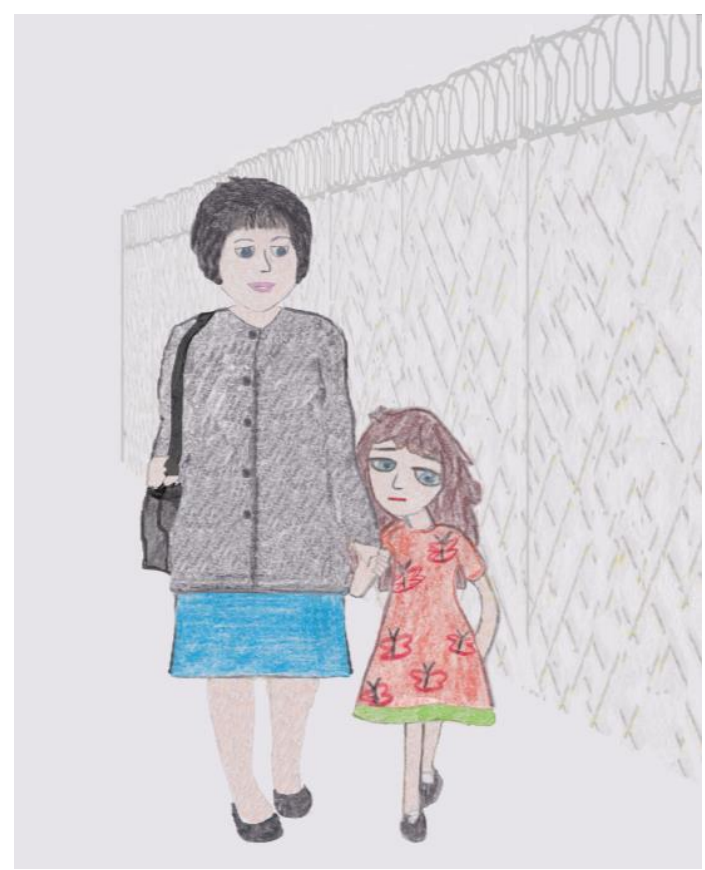

Figure 2. Sammy and her Grandma Approaching Correctional Centre

Mo Korchinski, a former correctional inmate and now a counselor to those dealing with post-release trauma has illustrated the story, Sammy's Visit. Her illustrations carry a child like quality. I got to know Mo when she was a student during her time of incarceration. She understands well the pain of being separated from ones children, and brings a level of authenticity to her drawings.

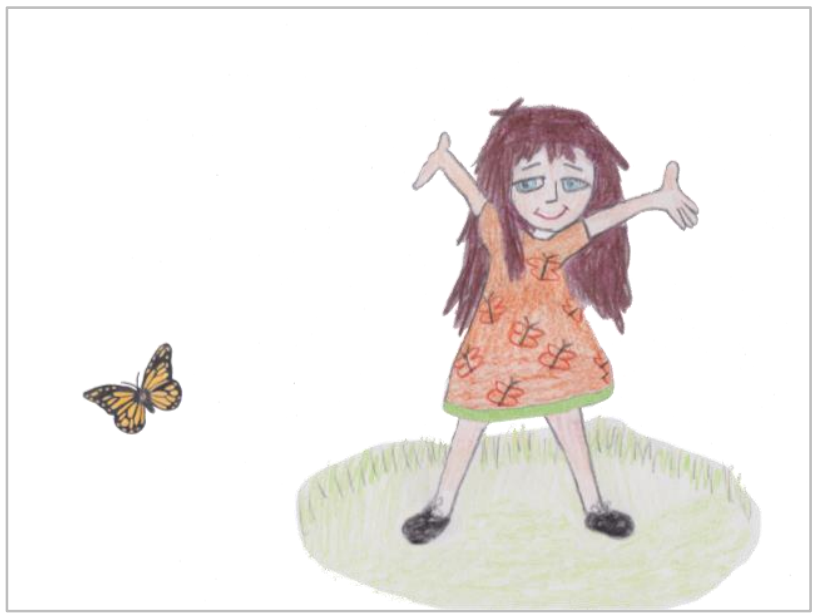

Figure 3. Sammy Dances with a Butterfly

Sammy's Visit is a realistic story about a day in the life of a child with an incarcerated parent. Sammy lives with her grandmother, who struggles to afford life's essentials. Lonely and missing her mother, Sammy struggles emotionally. The ache that sets in after each prison visit becomes unbearable, and consequently Sammy begins to resist these visits. Yet she loves her mother and values the intimate reading moments together, 
qualities that many children can relate to. Sadness, playfulness, confusion, and hope; a multiplicity of human emotions are woven together, inviting dialogue with respect to the first two dimensions of critical literacy.

The first dimension of critical literacy focuses on a shift in perspective. A typical perspective of jail might be one that regards all incarcerated people as "bad" or "scary". Sammy's Visit offers another view, that of someone who has a loving relationship with her daughter where fairy tales and poetry are positive points of connection.

The second dimension of critical literacy focuses on entering into the experiences of another. As children read the story, they follow and observe Sammy, and are also given access to her thoughts and feelings, making it easier to 'step into her shoes'. If Sammy's Visit has the potential to develop understanding, empathy, and a new perspective toward children whose parents are incarcerated, then such stories deserve to be told and have a place in Canadian schools.

\section{Methodology}

After receiving Ethics approval to conduct the research, I contacted schools and obtained consent at various levels for student participation, including: the divisional superintendent, school principals, parents, and students themselves. I worked with three focus groups of 5-6 student volunteers each, in the grade 3-5 range. I read this story to three groups of children in two schools and from two diverse communities. Students from Groups One and Two are from a rural, economically disadvantaged community where Child and Family Services are very active. Students from Group Three are from a rural, wealthy, middle-class community, where many of its residents are professionals. All three read-alouds were followed by rich discussions that were guided by a set of questions.

I introduced the story to each group by showing students the cover page, asking them to make predictions as to what they thought the story would be about. I also stopped throughout the reading of the story allowing students the opportunities to make new predictions and to express their thoughts. Says Rosenblatt, "To lead the student to have literary experiences of higher and higher quality requires constant concern for what at any point he brings to his reading, what by background, temperament, and training he is ready to participate in" (Rosenblatt, 1960, p. 307). After reading the story, I lead the groups in discussions, and students were again invited to share their thoughts and feelings. Guiding students in their reading says Rosenblatt, "means helping the student primarily to reflect on what he has made of the text." (1960, p. 309). These sessions were audio recorded, transcribed, and analyzed. I was interested to find out whether understanding and empathy would be expressed toward children of incarcerated parents and whether thoughts expressed by the children engendered feelings of inclusivity towards children of incarcerated parents.

\section{Findings and Discussion}

The children in all three groups appeared to be engaged throughout the activity and seemed to enjoy listening to and discussing the story. Students were able to work through the questions I posed and dynamic discussions emerged in each of the three groups. Students identified with Sammy, albeit to a greater or lesser extent; that is, most were willing to be friendly and comforting toward her, while many — but not all—went further and were eager to extend friendship. Upon considerable reflection and analysis of the 
transcriptions, I categorized the children's comments and responses into five overarching themes. I will briefly discuss each of these. Children's quotes are sometimes used to illustrate a point and to provide greater depth and meaning to the overall discussion; all names have been changed to protect the identities of the children.

\section{Theme \# 1: Life Experiences Impacts Empathy}

Consistent with studies showing that children are able to empathize with others at a young age (examples: Dixon, Murray, and Daiches, 2013; Smith-D'Arezzo and Thompson, 2006), all the children who participated in this study expressed empathy toward the story's main character, Sammy. However, it was clear that their starting points were not the same. Community demographics appeared to impact the way in which the children responded to various aspects of the story, Sammy's Visit. Most notably, understandings of the world of poverty and incarceration appeared to be quite different from one group to another. For example, when a food bank is referred to in Sammy's Visit, the children were asked if they knew what this was. No one in Group Three seemed to know, whereas there were many knowing nods among children from Groups One and Two. Here is a sample of responses from Group Two:

Alex: Isn't it like where people donate food and other people can pick up food from there?

Amber: I think a food bank is, like for people who don't make a lot of money. It's kind of like a charity where you just drop off stuff for people who really need it.

Thomas: Where you get food for free.

Children in Group Three, on the other hand appeared to understand neither the concept nor function of a food bank, as seen in the following excerpt:

Morgan: A food bank is um, like uh, grocery store.

Annie: It's um, so it's where you go shopping at like in the day and you buy food.

Children from Groups One and Two seemed more familiar and even at ease with the concepts of poverty and incarceration. For example, words used at their own initiative and not found in the story, such as "foster" and "house arrest" reflect such understandings. Lacking in this same kind of knowledge and experience, the children from Group Three seemed to rely on the stereotypic images of jail as reflected in some of their responses. For example - pointing to an illustration, Brett said, "So like, they said they sat on a couch there. But there is no couches at jail."

On the other hand, other parts of the story elicited more knowledgeable responses from children in Group Three than from the other two groups. For example, early in the story when Grandma is cooking soup, she teases Sammy: “...it's stone soup, like the story your mom read to you last time." When I asked the children if they were familiar with the story Stone Soup, all of the children in Group Three responded positively, and seemed eager to discuss it, while I was faced with blank stares from the children in Groups One 
and Two. Children's interest to the different aspects of the story depends on the backgrounds they bring to the story. Says Rosenblatt, "The quality of our literary experience depends not only on the text, on what the author offers, but also on the relevance of past experiences and present interests that the reader brings to it" (1960, p. 305).

\section{Theme \# 2: Identifying with Mixed Emotions}

All participants from the three focus groups talked about the emotions-often mixed emotions - that the protagonist, Sammy experiences and exhibits throughout the story, Sammy's Visit. Words that the children used to describe her feelings include: sad, happy, droopy, mad, scared, angry, frustrated, worried, alone, nervous, shy. Alice described her feelings metaphorically, "Her feelings kind of go up and down like waves." She also reflected on Sammy's inability to express her feelings: "Sometimes, I think that sometimes she can't let out her feelings like something's blocking her way."

When the children were asked if they had ever experienced mixed feelings, there were many nods as stories were freely shared. Children in all three groups identified feelings that come from the death of a loved one (including pets) as similar to the feelings of separation that Sammy experiences. Alice, a particularly expressive student from the first focus group had this to say, "Sometimes, like when one of my loved ones pass away, and you're sad, and — but then when you think of the happy things you did together, it kind of brightens you up."

\section{Theme \# 3: Perceptual Shifts: Fear Turns to Warmth}

The first sentence of the story, Sammy's Visit elicited two very different responses from children representing the two communities. After some initial conversation where children made predictions about the story and talked about who Sammy might be, I began to read to Group Three.

Researcher: " 'Grandma, I don't want to visit Mom tomorrow', said Sammy as she shuffled, barefoot, into the kitchen of their tiny apartment." So who is Sammy?

Annie: $\quad$ That girl [pointing to the picture of Sammy]. But why doesn't she want to visit her mom? [voice rising] Sammy's mom is the one who made her!

Using the same story prediction process, by reading only the first sentence of the story as with Group Three above, the children from Group Two had a lot to say about why Sammy may not want to visit her mom. Note how differently the children in Group Two viewed Sammy's mother:

Kylie: $\quad$ Maybe because she's bad.

Researcher: Maybe who's bad?

Kylie: $\quad$ Her mother.

Alex: $\quad$ Maybe her mother beats her.

Kylie: $\quad$ Or abandons her. Maybe her mother abandons her. 
At this point in the story, all that is known is that Sammy doesn't want to go visit her mother. It is interesting that a child from each of these groups instinctively took "sides" with either Sammy or her mother. Annie from Group Three rebuked Sammy for not wanting to visit her mom. Conversely, Kylie and Alex from Group Two appeared to assume the worst in Sammy's mother.

As the story progresses to the next page, the difference in the way Sammy's mother is perceived continues, albeit subtle. Brett from Group Three said: "So maybe she like slept over at her granny's, and she likes sleeping over there, and yeah." Courtney agreed, "I think she doesn't want to do that because um, she likes to stay with her grandma longer and stuff." According to these responses, Sammy is having a good time at her grandma's house, and doesn't want to leave; the comments suggest that her reluctance to leave has little to do with her not wanting to see her mother. Group Two on the other hand had already decided that the mother is "bad," and they continued to develop this scenario. Susie suggested, "Maybe Sammy's a foster child."

Simon and Alice from Group One did not appear to side with one or the other, but simply tried to understand the disconnect between mother and daughter as seen in this thoughtful exchange:

Simon: Um, because maybe there's something going on in her life or with her mom.

Alice: Maybe she misses her mom.

By the time it becomes apparent in the story that Sammy's mother is in jail, not only had children in Group Two predicted that she is in jail, but Raylene and Kylie had also predicted why she is serving time: "She went to jail cause she did something bad, like...murder." However, the children in Group Three expressed astonishment when they discovered that Sammy and Grandma's destination is a correctional centre.

Children from all three focus groups expressed nervousness and in some cases fear of Sammy's mother. Yet, once the children had met Sammy's mother or at least by the end of the story, they all said softer and warmer things about her. For example, at the end of the story, when asked what they thought about her as a mom, this idea was expressed:

Courtney: She seems like, um like a really nice mom. And she doesn't like being in jail away from her daughter. And she wants to get out and be free and stuff.

Alex: $\quad$ She's a very nice mother.

Amber: Like how you think something really bad about her, but then you actually find out that at the end it's all good. And if you're mad at somebody then you could just say at the end, it's good.

When asked how they would feel if their mom or dad would go away for a really long time, responses from children in all three groups expressed sorrow. For example:

Annie: $\quad$ My heart would be broken.... I LOVE my parents!

Many voices: Alone, sad, afraid, scared, lonely.

Simon: $\quad$ You could be scarred for life because you don't know if your parents 
are coming home or not.

Perceptions about Sammy's mom shifted in all three groups. Such perceptual shifts characterize Lewison et al's (2002) first dimension of critical literacy - that which disrupts the commonplace. These perceptual shifts, however had different starting points. The children in Group Two who initially expressed harsh judgment toward Sammy's mom expressed more grace and compassion toward her by the end of the story. On the other hand, the incarceration of Sammy's mom is not something that was anticipated by the children of Group Three. They had expressed no ill feelings toward her up to that point and found the revelation of her incarceration to be unsettling. At this point, they expressed nervousness and fear, but by the end of the story, they too were expressing greater compassion. Children in Group Two were somewhat surprised to learn of the mother's incarceration, and they were saddened by it. Their feelings of nervousness also shifted to care and compassion. Figure 4 illustrates perceptual shifts that occurred with all of the groups. Groups One and Two shifted from negative to positive feelings, while Group Three shifted from positive to negative feelings and slowly shifted in a more positive direction again. Although children from Group Three were less positive about Sammy's mom at the end of the story than children from the other two groups, the perceptual shifting they experienced was in fact greater.

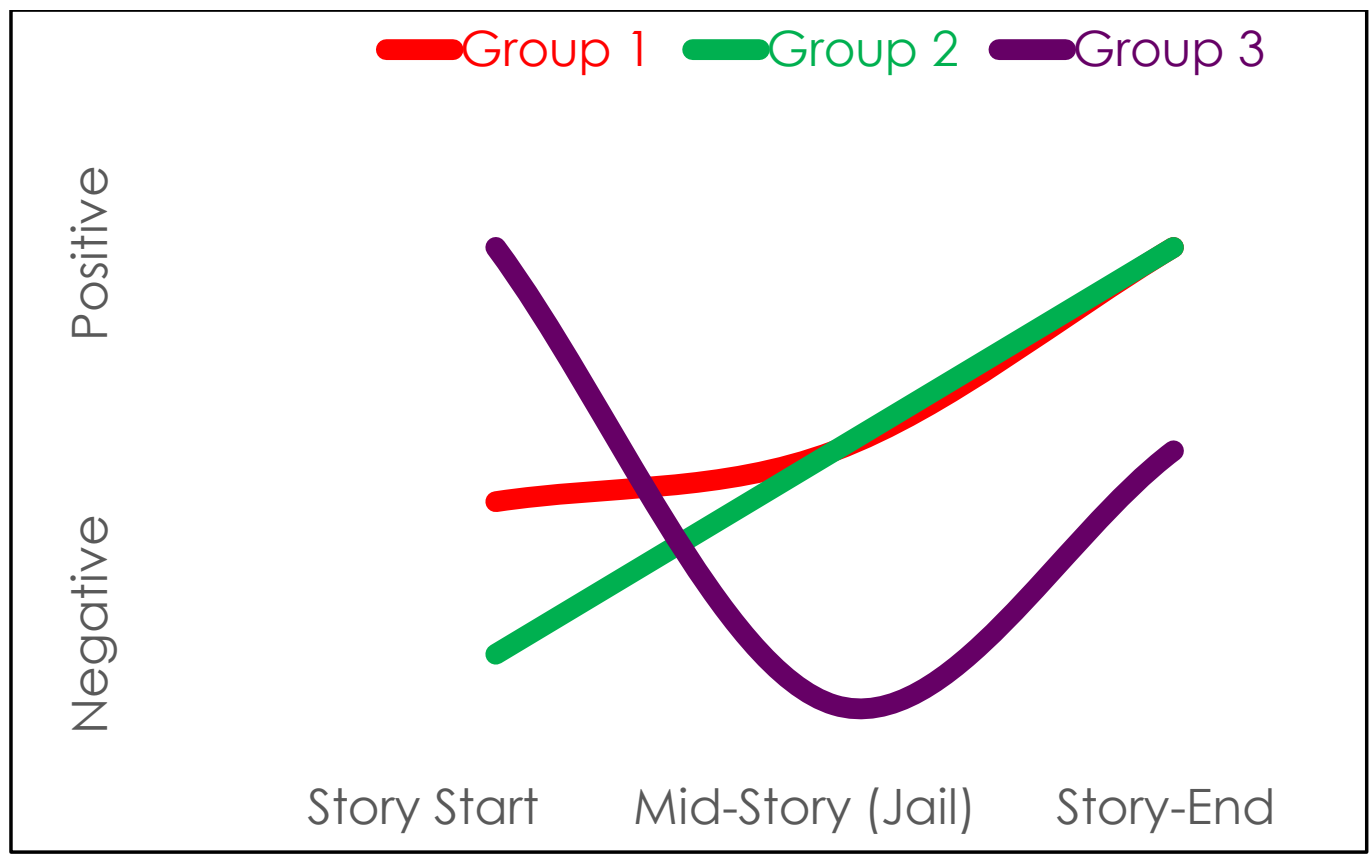

Figure 4. Perceptual Shifts

The third dimension of critical literacy is also evident here. Encountering Sammy's mom had the children thinking and talking about the justice system, which Sammy's mother is a part of. As the children came to know and like Sammy's mom, they also became more upset by her incarceration. While some suggested her arrest and imprisonment might be an "accident" and preferred to believe that she was falsely accused and sentenced, others assumed wrong doing and tried to understand it, as Morgan's comment reflects: "I think she mighta got into jail because maybe she didn't have enough money and she had to steal 
money and then she got into jail." This touches on Lewison et al's (2002) third dimension of critical literacy: focusing on socio-political issues. Though the children didn't pursue the discussion further by questioning the fairness of the judicial system, the groundwork is being laid for future engagement in such critical and important conversations.

\section{Theme \# 4: Embodying an Ethic of Care: Story Elicits Empathy}

After children identified that Sammy has a problem, they were asked what they might do to help her feel better. There were no end of suggestions from the children in Group One and Two as they offered cookies and cupcakes and expressed eagerness to play with her, embodying the ethic of care that Noddings speaks about.

Many of the children in Group One seemed to recognize that people who are sad require two things: an antidote of happy distractions as well as the opportunity to talk about one's feelings. Alice included both of these ideas in the same sentence, "I would talk about how she feels so that I can think of a way to help her and then play with her or something." Simon, expressing a deep understanding of human needs, took this a step further and said, "We could tell her how we feel, so she's more comfortable to tell us how she feels." He expressed empathy as he tried to imagine how she would feel and what her needs might be. He also recognized the important role that Sammy's grandmother plays in helping Sammy, as seen in this comment: "She's trying to keep strong in front of Sammy." Simon did not have difficulty looking at things from the perspective of others, which is an example of Lewison et al's (2002) second dimension of critical literacy, that of interrogating multiple viewpoints. Courtney, from Group Three, also expressed empathy as seen in her comment, "Include her in all your games that you play and get her mind off her mother." But other responses from this group reveal that they had difficulty looking past the fact that Sammy's mother is in jail. To help her, they felt a need to address this problem. Brett proposed to help Sammy feel better by convincing her of her mother's innocence. Though this kind of "help" would almost certainly be harmful, what is clear in his tone is that it was offered from a heart of compassion. Morgan suggested he would 'buy' her mother out of jail. Neither realistic nor helpful, like Brett he offered this suggestion because he felt sorry for Sammy. These children were troubled by the plight of Sammy as seen by these responses:

Annie: My heart would be broken.

Brett: I'd say "God please bring back my parents!"

I probed further by asking whether it would be a good story for children like Sammy to read. The responses from the children in Group Three were decidedly against this idea as they wanted to shield Sammy from the feeling of sadness in the story. Students in Groups One and Two however did not seem so afraid of sadness, recognizing that it is part of life.

Group Two went on to talk about the hope found in the story. Said Kylie, "It would let them know that there's still hope. There's hope to come home. There's still hope." Amber said, "If you're going through something like that, this book's good. That way you'd know that you'll probably be ok at the end."

Offering friendship: Enthusiasm vs reluctance. Reaching out to Sammy in kindness and friendliness is a first step toward reaching out in friendship, a deeper type of reaching 
out. Students were asked whether they would want to be friends with Sammy if she went to their school. Children in Group One and Two were eager to befriend her. When asked what kind of things they would do with Sammy, the answers came in quick and excited succession with a focus on play and having fun-important components of friendship. Sleepovers and play dates with Sammy were discussed. Kylie had this to say: "I'd want her to come over. I'd ask her for her number. I'd invite her to eat lunch. I'd ask her if she wanted to play and if she wanted to be friends." They went on to suggest many games and activities they would play with Sammy. Noticeable in this list were activities, which took into account Sammy's enjoyments, such as making paper butterflies and writing poems. These children had paid careful attention to the story. Judging by the desires expressed to actively engage in friendship with someone who is lonely and marginalized, these children seemed ready to embrace Lewison et al's fourth dimension of critical literacy: taking action and promoting social justice (2002).

The responses from children in Group Three were surprisingly different than those from Groups One and Two. While one student expressed compassion and a desire to be Sammy's friend, four of the children voiced reluctance to do so. Of the four, Sheldon had initially said he would be her friend, but then he changed his mind: "I wouldn't want to hang out with her, but whenever you talk with her or something, try to cheer her up or something."

Morgan was also hesitant. He responded with, "Hmmm, let me think here. If my friend had a mother in jail then I'd probably be nice to her, but she wouldn't be like my 'friend friend'." This demonstrates the difference between being friendly and being friends; they were willing to be friendly, but more hesitant to engage in friendship. Both Morgan and Sheldon were moved by Sammy's loneliness, felt for her, and wished her well. To offer friendship however, seemed beyond their comfort levels. Though most of this group was not ready to offer unequivocal friendship to Sammy, the topic of this story had unsettled them. They felt compassion for Sammy, but they also felt fearful to reach out in friendship.

Though the children warmed up to and liked Sammy's mom once they came to know her, they were still uncomfortable with the fact that she is in jail, and this colored their desire to be a friend to Sammy. (It is interesting to note that when one of the children suggested that the mother might be in jail accidently, all of the children in Group Three were more comfortable with the idea of being Sammy's friend.) When asked about being a friend to Sammy, over half of them were caught in the middle. Brett's response represents this dilemma well. Brett clearly enjoyed the story. He was positive about it from the very beginning, interrupting with, "I like this book" and again mid way through, "I like this. I like this book so far." Yet he became uncomfortable with some of the questions like, "Would you want to be Sammy's friend?" He said he would want to be her friend, but not too close a friend to her. When he was asked to explain himself, this is the dialogue that followed:

Brett: $\quad$ Because her mom is in jail and she might be a criminal.

Researcher: Who might be a criminal?

Brett: Her mom! Cause she's in jail.

Even though no one felt that Mom's incarceration was Sammy's fault, it still caused apprehension about a general willingness to befriend Sammy, as indicated by 
Morgan's comment: “...she might follow through with her mom or something.” The conversation with Brett continued:

Researcher: So if you say, "No, I wouldn't want to be her friend because her mom's in jail", can you tell me what you mean by that?

Brett: $\quad \mathrm{K}$, maybe I got a different reason, but maybe I just like got lots of friends and I just got enough.

Researcher: You have enough friends?

Brett: $\quad$ Or maybe I could have some more, but...

I sensed an internal struggle. Early in the story (before the students were aware that Sammy's mother was in jail), Brett said that he really liked the story. Despite the fact that aspects of the story troubled him, at the end he was still positive about the story as seen in this interaction:

Researcher: Tell me what other kids your age would think about this story?

Brett: $\quad$ They would like it. [Unhesitatingly]

Researcher: Yeah? Tell me why? Did you like it?

Brett: Yeah!

Researcher: What did you like about it?

Brett: $\quad$ I like it because it's like a good story, and um it's ... yeah. I like it. It's a good story.

Researcher: What is good about the story?

Brett: Well, there's a butterfly.

\section{Theme \# 5: The Role of Literary Hooks in Critical Literacy}

Brett had made numerous comments regarding butterflies throughout the discussion. For example, he commented on all the butterflies on Sammy's dress, with a cheerful, "I know why the butterflies like her. Cause she's nice. She helps the butterflies. She feeds them every day." His awareness of the migratory patterns of monarchs and his enjoyment of butterflies in general were apparent throughout the reading. Though Brett had been challenged with some uncomfortable ideas, the butterfly offered a point of connection to the story that may have helped to sustain his positive feelings to the end:

Researcher: How would you feel if your teacher would read this story to your class? Brett: Oh yeah, I'd like that!

Brett was not alone in connecting with the aspect of butterflies in the story. A number of other children in this group expressed knowledge of and interest in the life cycle of butterflies. The group expressed distress at the thought of Sammy wanting to catch and restrain the butterfly.

When children in all three groups were asked whether Sammy reminded them of somebody they know or of a character from a book, responses from children in Groups One and Two showed that they understood Sammy's struggle. Some for example shared a memory of a person they knew who was in jail. In Group Three however, the responses to this question were quite different, and the connection to the butterfly once again emerged. Sheldon said, "She reminds me of - I forget the story-someone-who likes 
animals cause she likes butterflies." Connecting to Sammy's struggle may be incomprehensible to the children in Group Three as they were unable to name any personreal or fictional - that reminded them of someone from the margins of society. The experiences and daily realities of these children in this middle-class neighborhood school are very different than those from the more economically depressed community, serviced regularly by Child and Family Services. Learning about issues such as the one Sammy faces and learning to understand and identify with this story character, especially if it feels uncomfortable, may take some time, and may require other avenues of connection to the story for some children - and interestingly the butterfly seems to have been that point of connection for many in this group.

\section{Conclusion}

The question that I set out to explore was whether or not a picture book can help children to understand and be empathetic toward children such as Sammy, a child of an incarcerated parent. Consistent with studies showing that children are able to empathize with others at a young age (examples include: Dixon et al., 2013; Smith-D'Arezzo and Thompson, 2006), children who participated in this study expressed empathy toward Sammy. Though I found that these children all grew in their understanding and empathy toward Sammy, the starting points or background knowledge of the group participants was not the same. That is to say, the experiences and understandings of the world of poverty and incarceration appeared to be quite different from one group to another. Those from the community with a lower socio-economic demographic readily expressed empathy for Sammy, as seen particularly in their desire to befriend her. Though children from the middle-class community expressed reluctance to befriend Sammy, they actually experienced the greatest perceptual shifts as can be seen in Figure 4. Feelings of empathy among these children were still evident. For example, these children not only articulated Sammy's mixed emotions and feelings of sadness, they also expressed their own sadness for her. Even while expressing their reluctance to befriend Sammy (for reasons that included fear), other avenues of "help" for her were offered. Though many of their suggestions to help Sammy were neither realistic nor helpful (and were in some cases potentially harmful), the study reveals that the children were touched by Sammy's plight. Their lack of knowledge and their fearfulness show the need to develop greater awareness of the issues surrounding incarceration and its impact on children.

That a lack of experience affects ones ability to be empathetic is consistent with the findings of Dever et al. In their 2005 study, Using picture books as a vehicle to teach young children about social justice, they compare children's responses to Hoffman and Binch's Amazing Grace (the story of the African-American girl hoping for the main role in a school play) and Bunting's Fly Away Home (the story of the young homeless boy living in an airport with his father). Though Dever et al make a point of saying that both of these stories generated empathetic responses from children, they also add:

Children were better able to put themselves into the character of Grace than the homeless boy which may have assisted them to become advocates. This is probably because the context of a classroom and participation in a school play were within their realm of experiences, while living in an airport was not. The children in this project had never experienced homelessness any more directly than perhaps 
observing homeless people in their communities. Even then, they may not have been aware of what they were observing. Furthermore, they may have easily identified with Grace if they had personally experienced hurtful remarks from classmates. (p. 21)

Similarly, the concepts of both poverty and incarceration seem to be far away from the experiences of the children in Group Three, and they will need to hear more stories with such themes to grow in their empathy and understanding. The implications for learning are significant. When children's background experiences and knowledge are neither acknowledged nor welcomed, their literary experiences will lack meaningful connections to their lives. When schools insist on standardized, prepackaged reading materials that do not reflect the diverse populations that they serve, students will struggle to find linkages in what they read and will not know how to respond.

This study highlights the important role that broadly compelling and appealing story elements, sometimes referred to as "literary hooks," play in maintaining student interest. The more such hooks that are available, the better a chance that children will find avenues of connection, which will help to ensure that everyone is able to relate to the story at some level. For example, while some children felt at a loss to understand Sammy and her mother's reality, they connected with the theme of the butterfly (in this case, the butterfly is the 'hook"). When I wrote Sammy's Visit, I incorporated references to fairy tales, poetry, and ecology (butterflies) in part to offer teachers several avenues to other conversations that could be had with students. Yet, I was surprised when-without any prompting - I saw the children engage independently and with obvious pleasure with some of these motifs in the story. Rosenblatt speaks to this when addressing limitations of an author, who "may plan a particular book, but one cannot plan what children will take from it" (2001, p. 272). Critical literature will challenge students. While it is important for students to be challenged, stories that are too far from the reality of children make the stories too inaccessible for them. Students need to be pushed slowly, with patience and with gentleness. Connection points or hooks can allow students to focus on other areas of interest in a story, while giving the challenging themes the time they need to be processed. Some children will require more vicarious experiences through literature to give empathy time to grow and develop. Murris (2014) points out that since children have not had a lot of experiences, vicarious experiences can be offered to them through picture books. SmithD'Arezzo and Thompson (2006) remind us that reading books with believable characters helps children to grow in empathy.

The implications for teachers are broad. Teachers need to know their students and know what their interests are so they can encourage their students to pursue such topics of enjoyment. This in turn creates an atmosphere that allows teachers to introduce to their students new and perhaps uncomfortable themes in hopes of advancing student understanding and empathy. According to Noddings (2005) and Freire (1970), knowing our students is foundational to effective teaching; taking the time to know our students, helps to build trust.

Trust is needed for students to feel safe, especially when they are asked to venture into unknown or uncomfortable territory. For example, when students in Group Three were asked who would want to be a friend to Sammy, Sheldon initially put up his hand. When asked to elaborate on this, he looked embarrassed, and changed his answer to, "Ah, well, 
half and half. I would want to be a friend to her, but I wouldn't really be a friend." This caused a response of mild ridicule from another student: "That makes no sense." I needed to assure him - while explaining to the girl who ridiculed him — that just like Sammy, we all have mixed feelings at times. Sheldon seemed to relax and was able to express himself more freely saying that he would be nice to Sammy, while admitting he wouldn't really want to hang out with her. Assuring Sheldon that mixed feelings are normal is what seemed to help him to feel safe, and I believe this allowed him to be more honest about his feelings.

Murris (2014) says that picture books should not be used as a platform to moralize. Teachers should not get in the way or short circuit the process of students trying to understand their emotions. Only when students have a sense of understanding their own emotions, can we help them to move forward. Rosenblatt speaks to the importance of encouraging students to respond to text; in so doing, children develop the ability to reflect and know themselves better. Furthermore, dialoguing with other students about a story will highlight different views and perspectives and will lead to further self-discoveries. Rosenblatt (2001) sums this up well: "Discovering that others have had different responses, have noticed what was overlooked, have made alternative interpretations, leads to self awareness and self criticism" (p. 276).

\section{Final Thoughts}

Discussions around incarceration and its impact on children and learning have not been a part of the dialogue in many education circles. As the incarceration rates across the nation continue to climb, we as educators must do everything in our power to help the children of those in custody to be successful. Stories that focus on the experiences of children who are marginalized not only authenticate their realities, but the use of such literature can develop greater awareness among those who are not personally impacted by parental incarceration. When discussions are guided with sensitivity and care, such awareness can lead to greater understanding and empathy among children. By supporting our students to grow in their understanding toward the needs of children whose parents are incarcerated, we continue to create - together with our students - an ethic of care and a climate of inclusivity for all.

To order a copy of Sammy's Visit, please visit: http://www.sammysvisit.com. To get in touch with the author, email Val at: valmpr@icloud.com.

\section{References}

Bayes, S. (2007). Acknowledging and reaching children of prisoners. Canadian Children, $32(1), 12-18$.

Connell, J. M. (2005). Continue to Explore: In Memory of Louise Rosenblatt. Education and Culture, 21(2), 63-79.

Correctional Service of Canada, (2007, May). Incarcerated Fathers: A Descriptive

Analysis. Retrieved from http://www.csc-scc.gc.ca/research/r186-

eng.shtml\#number-incar

Correctional Service of Canada, (2011, November). Education and Employment

Programs. Retrieved from http://www.csc-scc.gc.ca/correctional-

programs/002001-3000-eng.shtml 
Dauvergne, M. (2012, October). Adult correctional statistics in Canada, 2010/2011.

Canadian Centre for Justice Statistics, Retrieved from http://www.statcan.gc.ca/pub/85-002-x/2012001/article/11715-eng.pdf http://www.statcan.gc.ca/pub/85-002-x/2012001/article/11715-eng.htm

Dever, M. T., Sorenson, B., Brodrick, J. (2005). Using picture books as a vehicle to teach young children about social justice. Social Studies and the Young Learner, 18(1), $18-21$.

Dixon, C., Murray, C., \& Daiches, A. (2013). A qualitative exploration into young children's perspectives and understandings of emotional difficulties in other children. Clinical Child Psychology and Psychiatry, 18(1), 72-90. doi:10.1177/1359104511433194

Dresang, E., McClelland, K. (1999). Radical Change: Digital Age Literature and Learning. Theory Into Practice, 38(3), 160-167.

Freire, Paulo. (1970). Pedagogy of the oppressed. London: Penguin Books.

Labadie, M., Pole, K., \& Rogers, R. (2013). How kindergarten students connect and critically respond to themes of social class in children's literature. Literacy Research and Instruction, 52(4), 312-338. doi:10.1080/19388071.2013.809176

Lea, B. (2015). Children's books about special needs used as a mediating tool, the perceptions of inclusion classroom teachers in mainstream schools. Higher Education Studies, 5(1), 51-62.

Lewison, M., Flint, A. S., \& Van Sluys, K. (2002). Taking on critical literacy: The journey of newcomers and novices. Language Arts, 79(5), 382-392.

Lowe, D. F. (2009). Helping children cope through literature. Forum on Public Policy Online, 2009(1), 1-17.

Luke, A. (2012). Critical literacy: Foundational notes. Theory into Practice, 51(1), 4-11.

Lysaker, J., \& Sedberry, T. (2015). Reading difference: Picture book retellings as contexts for exploring personal meanings of race and culture. Literacy, 49(2), 105-111.

Maich, K., \& Belcher, E. C. (2012). Using picture books to create peer awareness about autism spectrum disorders in the inclusive classroom. Intervention in School and Clinic, 47(4), 206-213. doi:10.1177/1053451211424600

McCormick, A. V., Millar, H. A., Paddock, G. B., \& Cohen, I. M. (2014). In the best interests of the child: Strategies for recognizing and supporting canada's at-risk population of children with incarcerated parents University of the Fraser Valley. Centre for Safe Schools and Communities.

Miller, D. L. (2012). Literature opens doors for all children. Phi Delta Kappan, 94(4), 2833.

Morgan, J., Leeson, C., Dillon, R. C., Wirgman, A. L., \& Needham, M. (2014). 'A hidden group of children': Support in schools for children who experience parental imprisonment. Children \& Society, 28(4), 269-279. doi:10.1111/chso.12012

Murris, K. (2014). Reading philosophically in a community of enquiry: Challenging developmentality with Oram and Kitamura's Angry Arthur. Childrens's Literature in Education, 44(2), 145-165. doi:10.1007/s10583-013-9205-8

Nikolajeva, M. (2013). Picturebooks and emotional literacy. The Reading Teacher, 67(4), 249-254. 
Noddings, N. (1988). An ethic of caring and its implications for instructional arrangements. American Journal of Education, 96(2), 215-230.

Noddings, N. (1995). Teaching themes of care. Phi Delta Kappan, 76(9), 675-79.

Noddings, N. (2005). What does it mean to educate the whole child? Educational Leadership, 63(1), 8-13.

Noddings, N. (2012). The language of care ethics. Knowledge Quest, 40(5), 52-56.

Public Services Foundation of Canada. (2015, April). Crisis in Correctional Services: Overcrowding and inmates with mental health problems in provincial correctional facilities. Retrieved from http://publicservicesfoundation.ca/content/crisis-correctional-services

Riquelme, E., \& Montero, I. (2013). Improving emotional competence through mediated reading: Short term effects of a children's literature program. Mind, Culture, and Activity, 20(3), 226-239. doi:10.1080/10749039.2013.781185

Rosenblatt, Louise M. (1960). Literature: The Reader's Role. The English Journal, 49(5), 304-316.

Rosenblatt, Louise M. (2001). The Literary Transaction: Evocation and Response. Theory Into Practice, 21(4), 268-277.

Russell, Anne. (2014, October). UFV study looks at supporting children of incarcerated parents (Blog post). Retrieved from http://blogs.ufv.ca/blog/2014/10/ufv-studylooks-supporting-children-incarcerated-parents/

Sapon-Shevin, M. (1999). Because we can change the world: A practical guide to building cooperative, inclusive classroom communities. Needham, MA: Allyn \& Bacon.

Smith-D'Arezzo, W. M., \& Thompson, S. (2006). Topics of stress and abuse in picture books for children. Children's Literature in Education, 37(4), 335-347.

Statistics Canada. (2015, November). Adult correctional statistics in Canada, 2013/2014. Retrieved from http://www.statcan.gc.ca/pub/85-002-x/2015001/article/14163eng.htm\#a6

Statistics Canada. (2016, January). Canada's crime rate: Two decades of decline.

Retrieved from http://www.statcan.gc.ca/pub/11-630-x/11-630-x2015001-eng.htm

Statistics Canada. (2013, August). Demographic Overview of Aboriginal Peoples in Canada and Aboriginal Offenders in Federal Corrections. Retrieved from http://www.csc-scc.gc.ca/aboriginal/002003-1008-eng.shtml

Author Biography

Val Plett Reimer began her education career in an elementary classroom in Canada's arctic and has since worked in areas of Learning Resource, EAL, and Adult Education. The years she spent teaching high school courses in a women's correctional centre in British Columbia inspired the writing of Sammy's Visit. As women in the centre shared their stories about their children and families, the plight of Canada's "hidden children" became more clear. In response, Val combined her passion for children's literature with the desire to develop greater awareness and understanding of this hidden demographic of children. Together with her husband-also a teacher-Val currently teaches in a 2-room school in a small northern Manitoba community. They have three adult children. 